\title{
ASSESSMENT OF ROLES OF TREES TO RURAL LIVELIHOOD IN BUNZA LOCAL GOVERNMENT, KEBBI STATE
}

\author{
Umar I., Zogirma, F.U., Gwimmi D. P., Ambursa A. S., Abdulrahman A. and \\ Mustapha, M
}

Department of Forestry and Fisheries, Kebbi State University of Science and Technology, Aliero, Kebbi State iliyasudyu@gmail.com,

\begin{abstract}
The importance of tree to people and the environment was the aim of this paper. The Research was carried out at Bakura Local Area of Kebbi State. Questionnaire was used to get feedback from the farmers. The results that show the socio-economic status reveal that most of the dwellers in the local government use trees for shelter, food, medicinal, fodder, and fuel wood. Majority of the respondents (57.1\%) in the area reported that they were married, (24.3\%) were single, divorce (16.8\%) while widows have (1.5\%). This indicated that majority of the respondents have family responsibilities to cater for which affecttheir farming activities. Majority of students were male and only few were female, adults dominate the study area. On the education level, it was reported that primary education recorded (30\%) of the respondents in the study followed by tertiary education (27.1\%), secondary education had (11.5\%) while quranic education had (15.9\%). It is recommended that farmers should practice agro-forestry services, because of its dual benefits that people got from it and it also leads to successful recycling of nutrients and soil protection as well as improving their livelihood and agricultural production. Government should provide alternative source of living in the area so as to reduce the pressure on forest trees.
\end{abstract}

Keywords: Questionnaire, Environment and Tree Species 


\section{INTRODUCTION}

According to (FAO 2010) Forests are dominant terrestrial ecosystem of the earth, which are distributed across the account to $75 \%$ of the gross primary production of earth biosphere, and contain $80 \%$ of the earth plant biomass (FAO 2010). The distribution and abundance of different tress species over a landscape is what constitutes diversity in respect of tress species (Tripath, 2009).

In every land and in all age forest have an influence on the progress and welfare of human being. The progress from premature cave dwellers to the present civilized State cannot behold without frequent references to trees and their product. Trees provide early inhabitant with food, medicine, fuel, shelter, protection and other needs (FAO 2O10). Today over 10,000 products are reportedly made of wood. Vegetation provide food, shelter habitat and other number of services to humans, trees are such crucial components of ecology system that have productive and recreative functions this agreed with Rima, K (2019). They control soil erosion, stabilize regional and global climate change service as carbon sink and act in pollution control. Another issue worth notingis that tree height and length of the live crown do not affect the estimate of canopy cover, whereas canopy cover increase as the trees become taller, and as the height to the live base of the crown decreases (Husch, et al., 2003). Due to major difference in terms of life form and regeneration with understory plant species playing important roles in the overall plant species diversity in such ecosystem (Gilliam, 2007). Pressure on forest especially in the tropical world, due to economic resources provision from it now receive geometric increase of human population in the region (Salami, 2006). Thus this has led to unabated deforestation, which has been recognized as one of the major drivers of biodiversity loss in many region of the world (Ojonigu et al., 2010). According to FAO (2005), in each year about 13 million hectares of world's forest are lost due to deforestation and other anthropogenic factors. As a matter of fact one of the major concern of forest managers in resources development is the maintenance of plant diversity especially the predominant trees ( Aubert et al., 2003; Ellum et al., 2010).Deforestation and overexploitation of trees and clearing of natural vegetation as a result of conversionof forest into the agricultural lands, shifting cultivation, due to infertility of the farm lands, high or excessive cutting of trees for firewood and local roofing and converting woody trees into logs, overgrazing, bush burning, debarking of trees for traditional medicine in Bunza local government area, especially the recent use of bark of (Diospyros mespilipormis with the English name Ebony tree, which is called Kanya in Hausa due to its medicinal value which are used by many dwellers in curing many diseases in the study area.

The negative effect of poor plant distribution in the study area causes desertification, high temperature, low humidity and drought. Therefore, an accurate data is needed to have information on tree species available for proper planning and sustainable management of trees in the study area.

\section{Study Area}

The study was carried out in Bunza Local Government Area (LGA) of Kebbi State, Nigeria. The Local Government has it administrative headquarters in Bunza township. The Local Government was created in 1975 from former Sokoto State during the local government reform of the administration of General Murtala Ramat Mohammad. Bunza is bounded in the 
east by Kalgo Local Government Area, in the north by Dandi and Arewa Local Government in the south and west by Suru Local Government Area.

Bunza local government fall within Kebbi central senatorial zone alongside with Birnin Kebbi, Aleiro, Gwandu, Kalgo, Koko/Beese and Maiyama Local Government Areas. The Local Government forms a federal constituency alongside with Birnin Kebbi and Kalgo Study Areas. Agriculture is the main occupation of the inhabitant of Bunza Local Government has a population of 1, 2746 and it lies on the latitude $12^{0} 05,98 \mathrm{~N}$ and Longitude $4^{0} 01,16^{0} 0 \mathrm{E}$.

\section{Sampling Techniques}

The study area and the respondents were purposively selected from four districts in Bunza Local Government Area of Kebbi State, which include Bunza, Zogirma, Tilli and Raha, districts. Assessment of the importance of tree to the people and environment were asses with the aid of questionnaire which were administered to 25 purposely selected respondentsin each village making a total of 100 questionnaires and they were retrieved at the end of the administration.

\section{Data Analysis}

The data collected were subjected to descriptive statistics such as bar chart, frequency distribution Table and percentage were used for the interpretation of the results.

\section{RESULTS}

\section{Socio-economic Characteristics of the Respondents}

Table1: showed that $26.8 \%$ were within the range of $30-40$ years, $25.3 \%$ of the respondents were within the age of $40-50$ years, $17.1 \%$ of the farmers have attained the age range of 20-30, 18.7\% of the farmers were 50-60 years of age, while 60-70 years of age range constituted $6.2 \%$ of the total respondents. Males formed the majority of the respondents with $99.1 \%$ and female the minority with $0.9 \%$. Majority of the respondents $(57.1 \%)$ in the area reported that they were married, $(24.3 \%)$ were single, divorce $(16.8 \%)$ while widows have $(1.5 \%)$. This indicated that majority of the respondents have family responsibilities to cater for which affect their farming activities.

On the education level, it was reported that primary education recorded $(30 . \%)$ of the respondents in the study followed by tertiary education $(27.1 \%)$, secondary education had $(11.5 \%)$ while quranic education had $(15.9 \%)$. 
Table 1: Socio - economic characteristic of the respondents (100)

\begin{tabular}{|c|c|c|}
\hline Variables & Respondent & proportion (\%) \\
\hline \multicolumn{3}{|l|}{ Age (Year) } \\
\hline $20-30$ & 55 & 17.1 \\
\hline $30-40$ & 86 & 26.8 \\
\hline $40-50$ & 81 & 25.3 \\
\hline $50-60$ & 60 & 18.7 \\
\hline $60-70$ & 20 & 6.2 \\
\hline $70-80$ & 18 & 5.6 \\
\hline Total & 320 & 100 \\
\hline Married & 183 & 57.1 \\
\hline Single & 78 & 24.3 \\
\hline Divorced & 54 & 16.8 \\
\hline Widowed & 5 & 1.5 \\
\hline Total & 320 & 100.0 \\
\hline \multicolumn{3}{|c|}{ Educational attainment } \\
\hline Primary & 96 & 30 \\
\hline Post-Secondary & 84 & 27.1 \\
\hline Qur'anic education & 51 & 9.3 \\
\hline Adult class & 30 & 15.9 \\
\hline Nomadic & 19 & 5.9 \\
\hline Total & 320 & 100 \\
\hline \multicolumn{3}{|l|}{ Occupation } \\
\hline Farming & 120 & 37.5 \\
\hline Craft & 78 & 24.3 \\
\hline Business & 69 & 21.5 \\
\hline Civil servant & 53 & 16.5 \\
\hline Total & 320 & 100.0 \\
\hline
\end{tabular}

Source: Field survey 2018. 
Table 2: The result reveals that, $(24 \%)$ the respondent in the study area agreed that majority of them utilized trees for soil erosion control, (18.1.\%) of the respondents made mention that, the use of tree plant is to restore soil fertility, (12.8) prevention of desert encroachment, wind while only $7.8 \%$ said the use of a forestation were provision of shade. This showed that insufficient soil cover poses problem in afforestation. In Nigeria, Lal et al. (1979) observed that afforestation improve the cover of soil nutrient. The resultbobtainshowbthat fuelwood has highest of $23.1 \%$, followed by food $22.1 \%$, medicine 19.35 fodder 6.25 while manure has the least5.3\%. This agreed with Koh et al. (2004) \& Pimm and Raven (2000). Habitat destruction is the leading cause of species extinction and biodiversity loss in natural ecosystems, decreasing of species are numerous, but the most important is the human interference in the form of burning and clearing for cultivation, fuel wood, fodder etc. According to Thomas, Ryan (2019), forests are disappearing at an alarming rate owing to deforestation for extraction of timber and other forest produce or total conversion to other uses. Trees are one of the major structural components of forest ecosystems. Trees can reduce air temperature by blocking sunlight. Further cooling occurs when water evaporates from the leaf surface. The conversion of water to air vapour, a chemical process removes heat energy from the air.

\section{Assessment of Roles of Trees to Rural Livelihood}

Table 2: How many trees did you know?

\begin{tabular}{lcc}
\hline Name of tree & Respondent & \% \\
\hline Azadirachta indica & 43 & 13.4 \\
Butilaria paradozom17 & 5.3 & \\
Vitex doniana & 38 & 11.8 \\
Mangifera indica & 72 & 22.5 \\
Fiscus cycomorus & 21 & 6.5 \\
Combretum glutinosum & 61 & 19.0 \\
Adamsonia digitata & 78 & 7.8 \\
Hyaphane theobic & 30 & 9.3 \\
Philiostigma toningii & 13 & 4.0 \\
Total & 320 & 100 \\
What Importance Did You Derivev From Trees? & \\
Shelter & 37 & 11.5 \\
Medicine & 62 & 19.3 \\
Food & 71 & 22 \\
Fodder & 20 & 6.2 \\
Manure & 17 & 5.3 \\
Fuel wood & 74 & 23.1 \\
Farm tools & 39 & 12.1 \\
Total & 320 & 100 \\
What are the contributions of trees to your environment? & \\
Soil erosion control & 77 & 24.0 \\
Desertification control & 39 & 12.1 \\
\hline
\end{tabular}




\begin{tabular}{lcc}
\hline Shelter belt & 31 & 9.6 \\
Wind break & 25 & 7.8 \\
Restoration of soil fertility & 58 & 18.1 \\
Beutification & 41 & 12.8 \\
Cooling of Environment & 49 & 5.3 \\
Total & 320 & 100 \\
Which part of tree did you use more? & & \\
Fruit & 44 & 13.7 \\
Nut & 33 & 10.3 \\
Bark & 68 & 21.2 \\
Stem & 24 & 7.5 \\
Root & 71 & 22.1 \\
Leaf & 52 & 16.2 \\
Flour & 28 & 8.1 \\
Total & 320 & 100 \\
Is a tree having any disadvantage to you? & & 43.4 \\
Reducing the size of farm land & 139 & 12.8 \\
Reducing crop yield & 41 & 37.5 \\
Reducing light penetration from the sun & 125 & 4.6 \\
None & 15 & 19.37 \\
Which value does a tree add to your farm crops? & 62 & 10.3 \\
Increasing yield & 33 & 28.1 \\
Conserving mulching & 90 & 13.7 \\
Make plant grow fast & 44 & 100 \\
Increasing farmers' income & 320 & \\
Total & & \\
\hline
\end{tabular}

\section{DISCUSSIONS}

Table1: showed that $26.8 \%$ were within the range of $30-40$ years, $25.3 \%$ of the respondents were within the age of $40-50$ years, $17.1 \%$ of the farmers have attained the age range of $20-30,18.7 \%$ of the farmers were 50-60 years of age, while 60-70 years of age range constituted $6.2 \%$ of the total respondents. Males formed the majority of the respondents with $99.1 \%$ and female the minority with $0.9 \%$. This proved that male dominate agricultural work force in the study area. It agrees with Anselm A. E (2010) who reported that male dominated the agricultural workforce in Nigeria. The high proportion of males to females may be because religion and custom play vital roles in the livelihoods of the study area. For instance, males who are mostly the household heads, have more access to land and participate more in community activities than females.Majority of the respondents $(57.1 \%)$ in the area reported that they were married, $(24.3 \%)$ were single, divorce $(16.8 \%)$ while widows have $(1.5 \%)$. This indicated that majority of the respondents have family responsibilities to cater for which affect their farming activities. 
On the education level, it was reported that primary education recorded $(30 . \%)$ of the respondents in the study area followed by tertiary education $(27.1 \%)$, secondary education had $(11.5 \%)$ while quranic education had (15.9\%).

Table 2:The result reveals that, $(24 \%)$ the respondent in the study area agreed that majority of them utilized trees for soil erosion control, $(18.1 . \%)$ of the respondents made mention that, the use of tree plant is to restore soil fertility, (12.8) prevention of desert encroachment, wind while only $7.8 \%$ said the use of a forestation was provision of shade. This showed that insufficient soil cover posesproblem in afforestation. In Nigeria, Lal et al. (1979) observedthat afforestation improve the cover of soil nutrient.The resultobtainshow that fuelwood has highest of $23.1 \%$, followed by food $22.1 \%$, medicine 19.35 , fodder 6.25 , while manure has the least 5.3\%,This agreed with (Koh et al., 2004; Pimm and Raven, 2000).Habitat destruction is the leading cause of species extinction and biodiversity loss in natural ecosystems, decreasing of species are numerous, but the most important is the human interference in the form of burning and clearing for cultivation, fuelwood, fodder etc. According to Raghubanshi and Tripathi (2009) forests are disappearing at an alarming rate owing to deforestation for extraction of timber and other forest produce or total conversion to other uses. Trees are one of the major structural components of forest ecosystems. Trees can reduce air temperature by blocking sunlight. Further cooling occurs when water evaporates from the leaf surface. The conversion of water to air vapour, a chemical process removes heat energy from the air.

\section{Conclusion}

This study discovers the existence of different trees in the study area. But these species were being endangered as a result of over exploitation, fuel wood, charcoal production, bush burning and agricultural activities led to the environmental degradation. Rural people who engage into marketing of fuel wood and charcoal production and illegal felling of trees contribute to the discourage in making forestry research in the study area, Kebbi State, and Nigeria at large. 


\section{REFERENCE}

Anselm A. E and Taofeeq A. A ( 2010) Determinants of Women's Contribution to Farming Decisions in Cocoa Based Agroforestry Households of Ekiti State, Nigeria. Field Actions Science Reports The journal of field actions Vol. 4 | 2010 Vol. 4.

Aubert ,M .,Alard D., and . Burea F. (2003). Diversity of plant assemblages in manage temperate forest; a case study in Normandy (France). Forestecology and management, 172; 322- 327.

FOOD and Agriculture organization.(FAO) 2005. Forest resources assessment. Retrieved from http:/.www. fao.org/forestry/30515/enl retrieved $\quad 3^{\text {rd }}$ feb.2014.178Pp.

FAO. 2010. Global Forest Resources Assessment 2010. Rome (available at www.fao.org/forestry/fra/fra2010/en/).

Gilliam F.S. 2007. The ecological significances of the herbaceous layer in forest ecosystems. Bio science. 57: 845. 858.

Husch, B., T.W Beers and J. A Kershaw (2003). Forest mensuration, $4^{\text {th }}$ edition willey, new jersey ikonen V-P, 340Pp.

koh L. P., Dunn R. R., Sodhi N. S., Colwell R.K., Proctor H. C., Smith V.S. (2004). species coexitinction and their biodiversity crisis. Science 305, 1632-1634.

Ojonigu F.A, Tabitha S., Abbas , I , and Muhammad. S.O. (2010). Assessing changes in kogoro forest, Kaduna state, Nigeria. Using remote sensing and GIS. Journal of applied science, engineering and And technology 2(2): 121-132.

Rima, K., Ayan, B., Rahul, K., Amit K., Purabi, S., and Mohammed L.K (2019) Deforestation in India: Consequences and Sustainable Solutions, Submitted : October $5^{\text {th }} 2018$ Review: Dol: $10.5772 /$ intechopen. 85804

Salami, A.T. (2006): Towards a geo- information based forest monitoring in Nigeria. In: Salmi A.T (ed), imperatives of space technology for sustainable forest management in Nigeria proceeding of an international stake holders workshop sponsored by National Space Research and Development Agency (NASRDA), Abuja. Pp. 146160.

Tripathi A. and Raghubanshi, A.S. (2009). Effect of Disturbance, Habitat Fragmentation and a Line Invasive Plants on Floral Diversity in Dry Tropical Forest of Vindhyan Highlands: A Review. Tropical Ecology 50: 57-.

Tripath (2009) effect of disturbances. Habitat fragmentation and a line invasive plants on floral diversity in dry tropical forest of vindhyan high lands tropical ecology R.50; 57-69.34. USDA. (1967). Agricultural information bulleting no; 278 Washington D.C. 
Thomas, Ryan (2019). "Fundamental of Ecology". Marine Biology: An Ecological Approach (reprint ed.). Waltham Abbey, Essex: Scientific e-Resources (published 2020). p. 86. ISBN 9781839474538. Retrieved 8 March 2020. A habitat is an ecological or environmental area that is inhabited by a particular species of animal, plant, or other type of organism. The term typically refers to the zone in which the organism lives and where it can find food, shelter, protection and mates for reproduction. 